\title{
ANALISIS FINANCIAL DISTRESS PADA PERUSAHAAN AGRIBISNIS DI BURSA EFEK INDONESIA
}

\author{
Annisa Nurfajrina \\ Hermanto Siregar \\ Imam Teguh Saptono \\ Sekolah Bisnis - Institut Pertanian Bogor \\ Gedung SB IPB, Jl. Raya Pajajaran, Bogor - Indonesia 16151
}

\begin{abstract}
Agribusiness is one of important sector in Indonesia. Agribusiness has unique characteristics and high complexity which can lead to financial problems. Therefore, its important to analyzed financial distress in agribusiness company in order to avoid bankruptcy. This research analyzed financial factors that influence financial distress in agribusiness companies listed in Indonesia stock exchangeperiod 2010-2014. Eleven agribusiness companies were selected based on purposive sampling. This study used DSCR (debt service coverage ratio) as a proxy of financial distress. The method of analysis used panel data regression. The results showed that financial ratios are EBITDA to total assets, ROE, and TATO have a significant positive effect to DSCR. However, DAR and WC/TA have no significant effect to DSCR.
\end{abstract}

Keywords: agribusiness companies, DSCR, financial distress, panel data regression

\section{PENDAHULUAN}

Indonesia dikenal sebagai negara agraris dimana sektor agribisnis mempunyai peranan strategis dalam struktur pembangunan perekonomian nasional. Sektor agribisnis berperan sebagai penyedia bahan pangan dan bahan baku industri serta berkontribusi menghasilkan devisa negara. Hasil ekspor agribisnis pada tahun 2014 mencapai 31.6 miliar US dolar (Kementerian Pertanian, 2015a). Selama periode 2010-2014, sektor agribisnis menempati posisi terbesar kedua dalam kontribusi PDB Indonesia yaitu sekitar 13.5\% (BPS, 2015a). Sektor ini juga mampu menyerap tenaga kerja sekitar 30.2\% dari total tenaga kerja pada tahun 2014 (BPS, 2015b). Pada tahun 2014, total investasi di sektor ini mencapai 400 triliun rupiah dengan pertumbuhan investasi dalam negeri dan modal asing sebesar $4.2 \%$ dan $18.6 \%$ per tahun (Kementerian Pertanian, 2015b).

Krisis keuangan global yang terjadi berdampak negatif pada sektor agribisnis di Indonesia karena mengakibatkan permintaan global dan harga-

Korespondensi dengan penulis:

Annisa Nurfajrina, Telp. +62812-8380-4948

Email: nisajrina@gmail.com 


\section{Analisis Financial Distress pada Perusahaan Agribisnis di Bursa Efek Indonesia}

Annisa Nurfajrina, Hermanto Siregar, \& Imam Teguh Saptono

harga komoditas cenderung melemah. Selain itu, perekonomian Indonesia cenderung mengalami penurunan dalam lima tahun terakhir. Kondisi perekonomian yang melemah dan krisis global yang terjadi dapat mempengaruhi kinerja perusahaan agribisnis. Rizaldi (2000) menyatakan bahwa faktor makroekonomi menunjukan pengaruh yang cukup signifikan untuk kelompok saham agribisnis di Indonesia.

Ketika perusahaan mengalami banyak hambatan maka lambat laun perusahaan tersebut akan berada pada kondisi financial distress, yaitu kondisi dimana perusahaan tidak memiliki kapasitas untuk memenuhi kewajibannya (Andrade \& Kaplan, 1998). Financial distress didefinisikan sebagai tahap penurunan kondisi keuangan yang terjadi pada perusahaan sebelum terjadinya kebangkrutan ataupun likuidasi (Platt\& Platt, 2002).

Financial distressdapat diukur dengan menggunakan debt service coverage ratio (DSCR). Rasio ini menggambarkan seberapa besar perusahaan mampu menghasilkan dana untuk memenuhi kewajibannya. Stulpiniene dan Mazure (2013) menggunakan DSCR sebagai salah satu indikator dalammengukur financial distress of farm di Lituania, Eropa.Arlinda et al.(2015) juga menggunakan DSCR sebagai penentu kondisi financial distress industri telekomunikasiIndonesia.

Faktor fundamental berupa rasio keuangan dapat mempengaruhi kondisifinancial distress pada suatu perusahaan. Lemmon et al. (2009) mengukur financial distress menggunakan EBITDA to total asset dan model yang digunakan menunjukan bahwa rasio ini berdampak negatif terhadap financial distress.Apabila perusahaan memiliki nilai EBITDA to total asset yang kecil, perusahaan sudah tentu dalam kondisi financial distress karena tidak mempunyai kemampuan untuk membayar biaya overhead.

Penelitian Arasy dan Harlendro (2014) menggunakan analisis regresi logistik terhadap perusahaan tekstil dan garmen menunjukkan bahwa debt to asset ratio(DAR)merupakan prediktor yang dominan dalam memprediksi kondisi financial distress karena memiliki nilai koefisien regresi yang cukup signifikan. Namun, hasil yang berbeda ditunjukkan oleh Putri dan Merkusiwati (2014). Mereka membuktikan bahwa DAR tidak berpengaruh terhadap kemungkinan terjadinya financial distress perusahaan manufaktur di Indonesia.

Widati dan Pratama (2015) melakukan penelitian terhadap perusahaan manufaktur di BEI dan hasilnya menunjukkan bahwa return on equity (ROE) berpengaruh positif signifikan terhadap financial distress. Haq et al. (2013) meneliti financial distress pada perusahaan non-keuangan yang terdaftar di BEI. Hasil penelitiannya menunjukkan bahwa baik secara simultan maupun secara parsial rasio DAR dan ROEberpengaruh terhadap financial distress.

Penelitian Alifiah et al. (2013) menunjukkan bahwa DAR, total assets turn over (TATO), dan working capital ratio mampu memprediksi kesulitan keuangan di perusahaan konsumer Malaysia. Hidayat dan Meiranto (2014) menambahkan bahwa semakin besar rasio TATO yang dimiliki oleh perusahaan, maka semakin kecil kemungkinan perusahaan tersebut akan mengalami financial distress.

Ahmad (2013) menemukan bahwa terdapat hubungan negatif antara working capital to total assets (WC/TA) dengan financial distress pada perusahaan manufaktur yang terdaftar di BEI periode 2005-2010. Namun menurut Fitriyah dan Hariyati (2013), rasio keuangan WC/TA tidak memiliki pengaruh yang signifikan terhadap kondisi financial distress pada perusahaan properti dan real estate di Indonesia.

Penelitian mengenai financial distress telah banyak dilakukan di berbagai negara termasuk di Indonesia,namun hasil yang ditunjukkan berbedabeda tergantung dengan sektor yang dijadikan objek penelitian. Selain itu, masih jarang ditemukan analisis financial distress terhadap perusahaan agribisnis di Indonesia. Berdasarkan hal tersebut maka rumusan masalah dalam penelitian ini adalah 


\section{Jurnal Keuangan dan Perbankan | KEUANGAN}

Vol. 20, No.3, September 2016: 448- 457

menganalisis faktor-faktor keuangan yang mempengaruhi kondisi financial distress pada perusahaan agribisnis di Bursa Efek Indonesia.

\section{HIPOTESIS}

Hipotesis yang diajukan dalam penelitian ini adalah sebagai berikut:

1. $\mathrm{H}_{1}$ : DAR berpengaruh negatif signifikan terhadap DSCR

2. $\mathrm{H}_{2}:$ EBITDA/TA berpengaruh positif signifikan terhadap DSCR

3. $\mathrm{H}_{3}$ : ROE berpengaruh positif signifikan terhadap DSCR

4. $\mathrm{H}_{4}$ : TATO berpengaruh positif signifikan terhadap DSCR

5. $\mathrm{H}_{5}: \mathrm{WC} / \mathrm{TA}$ berpengaruh positif signifikan terhadap DSCR.

\section{METODE}

\section{Jenis dan Sumber Data}

Data yang digunakan adalah data sekunder berupa laporan keuangan perusahaan yang diperoleh dari BEI melalui website www.idx.co.id. Perusahaan yang diteliti pada penelitian ini adalah sektor pertanian (agriculture). Pengumpulan data dilakukan dengan menggunakan teknik purposive sampling dengan kriteria pemilihan sampel sebagai berikut:

- Perusahaan sektor pertanian yang terdaftar di BEI dan tidak delisting selama periode 20102014

- Laporan keuangan perusahaan lengkap dan telah diaudit

- Komponen-komponen yang diperlukan dalam proses perhitungan tercantum jelas di laporan keuangan.

\section{Operasional Variabel}

\section{Variabel Terikat (Dependent)}

Variabel terikat dalam penelitian ini adalah debt service coverage ratio (DSCR). DSCR mencerminkan kondisi perusahaandengan melihat ketersediaan dana untuk melunasi hutang perusahaan. Perusahaan dikatakan mengalami kegagalan atau financial distressapabila memiliki nilai DSCR $\leq$ 1.20(Ruster, 1996). $\mathrm{DSCR}=\frac{\mathrm{EAT}+((\text { Depreciation }+ \text { Amortization })+\text { Interest or Coupon })-\mathrm{Tax}}{\text { Principal }+ \text { Interest or Coupon }}$

Tabel 1 Daftar perusahaan pertanian yang dijadikan objek penelitian

\begin{tabular}{lcc}
\hline Kode & Nama Perusahaan & Subsektor \\
\hline BWPT & Eagle High Plantations Tbk. & Perkebunan \\
CPRO & Central Proteina Prima Tbk. & Perikanan \\
DSFI & Dharma Samudera Fishing Industries Tbk. & Perikanan \\
GZCO & Gozco Plantations Tbk. & Perkebunan \\
IIKP & Inti Agri Resources Tbk. & Perikanan \\
JAWA & Jaya Agra Wattie Tbk. & Perkebunan \\
SGRO & Sampoerna Agro Tbk. & Perkebunan \\
SIMP & Salim Ivomas Pratama Tbk. & Perkebunan \\
SMAR & SMART Tbk. & Perkebunan \\
TBLA & Tunas Baru Lampung Tbk. & Perkebunan \\
UNSP & Bakrie Sumatera Plantations Tbk. & Perkebunan \\
\hline
\end{tabular}




\section{Analisis Financial Distress pada Perusahaan Agribisnis di Bursa Efek Indonesia}

Annisa Nurfajrina, Hermanto Siregar, \& Imam Tegub Saptono

\section{Keterangan:}

\begin{tabular}{|c|c|}
\hline AT & : earning after tax \\
\hline Depreciation & $\begin{array}{l}\text { : alokasi biaya untuk pemanfaata } \\
\text { aset tangible }\end{array}$ \\
\hline mortization & $\begin{array}{l}\text { : alokasi biaya untuk pemanfaatar } \\
\text { aset intangible }\end{array}$ \\
\hline Interest & : beban bunga hutang bank per tahu \\
\hline Coupon & $\begin{array}{l}\text { : beban bunga obligasi perusahaar } \\
\text { per tahun }\end{array}$ \\
\hline $\operatorname{Tax}$ & : pajak korporasi per tahun \\
\hline Principal & $\begin{array}{l}\text { angsuran pembayaran pinjam } \\
\text { secara berkala atau pembayar } \\
\text { obligasi korporasi }\end{array}$ \\
\hline
\end{tabular}

\section{Variabel Bebas (Independent)}

Variabel bebas dalam penelitian ini adalah rasio-rasio keuangan yang diperkirakan mempengaruhi nilai DSCR yang tercantum di Tabel 2.

\section{Analisis Regresi Data Panel}

Data panel merupakan penggabungan data deret waktu (time series) dengan data yang terdiri dari beberapa objek (cross section).Dalam penelitian ini, data panel merujuk ke data yang berasal dari laporan keuangan masing-masing perusahaan agribisnis selama lima tahun terakhir (2010-2014).
Data time series yang digunakan adalah data tahunan untuk periode 2010-2014. Sedangkan data cross section yang digunakan adalah 11 perusahaan agribisnis yang dijadikan objek penelitian. Dalam penelitian ini, terdapat jumlah pengamatan sebanyak 55 observasi yaitu hasil perkalian jumlah tahun dengan jumlah perusahaan.Model penelitian yang digunakan adalah sebagai berikut:

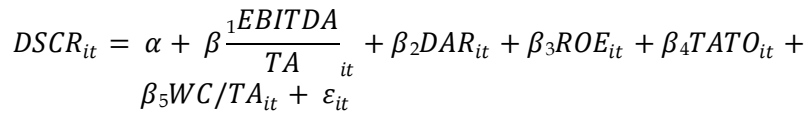

\section{Keterangan:}

DSCR : debt service coverage ratio

i $\quad: 1,2,3, \ldots .11$ (sebanyak jumlah perusahaan yang diamati)

t $\quad: 1,2,3, \ldots .7$ (sebanyak jumlah periode tahun yang diamati)

$\alpha \quad$ : koefisien intercept

$\beta_{x} \quad$ : koefisien slope dari variabel bebas

EBITDA/TA : ebitda to total assets

DAR : debt to assets ratio

ROE : return on equity

TATO : total assets turn over

WC/TA : working capital to total assets

$\varepsilon \quad:$ : komponen error

Tabel 2 Variabel bebas yang digunakan dalam penelitian

\begin{tabular}{lcc}
\hline Rasio & Variabel & Pengukuran \\
\hline Efisiensi & EBITDA/TA & pendapatan sebelum bunga, pajak, depresiasi, amortisasi \\
Leverage & DAR & $\begin{array}{c}\text { total aset } \\
\text { total kewajiban }\end{array}$ \\
Profitabilitas & ROE & $\frac{\text { total aset }}{\text { laba bersih }}$ \\
Aktifitas & TATO & $\frac{\text { total penjualan }}{\text { total aset }}$ \\
Likuiditas & WC/TA & $\frac{\text { aset lancar - kewajiban lancar }}{\text { total aset }}$ \\
\hline
\end{tabular}




\section{Jurnal Keuangan dan Perbankan | KEUANGAN}

Vol. 20, No.3, September 2016: 448- 457

\section{Pengujian Hipotesis}

Setelah data diolah, selanjutnya dilakukan pengujian terhadap hasil outputnya. Pengujian ini meliputi uji F, uji T, dan koefisien determinasi $\left(R^{2}\right)$.

1. Uji-F memperlihatkan ada tidaknya pengaruh variabel independen terhadap variabel dependen secara bersamaan. Pengujian ini dilakukan dengan melihat angka probabilitas. Jika p-value $<$ a $(\mathrm{a}=5 \%)$, maka variabel independen berpengaruh signifikan secara bersamaan terhadap variabel dependen.

2. Uji-t dilakukan untuk mengetahui signifikansi peran secara parsial antara variabel independen terhadap variabel dependen dengan mengasumsikan bahwa variabel independen lain dianggap konstan. Jika nilai t-stat $<\mathrm{a}(\mathrm{a}=5 \%)$, maka variabel independen secara parsial signifikan mempengaruhi variabel dependen.

3. Koefisien Determinasi $\left(R^{2}\right)$ mencerminkan kemampuan model dalam menerangkan variasi variabel dependen. Semakin besar nilai $\mathrm{R}^{2}$ maka semakin baik kemampuan variabelvariabel independen menjelaskan variabel dependen.

\section{HASIL}

\section{Analisis Deskriptif}

Analisis deskriptif dilakukan dengan menyajikan data kuantitatif yang bertujuan untuk memberikan gambaran umum mengenai objek penelitian. Analisis deskriptif menjabarkan nilai rata- rata (mean), median, nilai minimum dan maksimum, serta nilai standar deviasi.Tabel 3 menunjukkan statistika deskriptif variabel bebas dan terikat dari 11 perusahaan agribisnis yang terdaftar di BEI periode 2010-2014.

Hasil dari analisis deskriptif menunjukan bahwa nilai rata-rata (mean) DSCR sebesar 1.413. Hal ini dapat diartikan bahwa sebagian besar perusahaan agribisnis terbebas dari financial distress karena memiliki nilai DSCR diatas 1.2 (Ruster, 1996). Namun terlihat kesenjangan data yang cukup besar antara nilai maksimum dan minimum DSCR. Nilai maksimumsebesar 10.842dimiliki oleh perusahaan IIKP pada tahun 2010. Namun pada tahun 2011, IIKP mengalami rugi bersih yang sangat besar sehingga menyebabkan nilai DSCR nya mengalami penurunan yang sangat signifikan menjadi nilai minimum yakni sebesar -45.557.

DAR memiliki nilai mean sebesar 0.538 dan median sebesar 0.530. Nilai maksimum sebesar 0.985 , minimum sebesar 0.004 , dan standar deviasi sebesar 0.080. Nilai maksimum berasal dari nilai DAR perusahaan CPROdi tahun 2012 sedangkan nilai minimumnya berasal darinilai DAR perusahaan IIKP tahun 2010 dan 2011. Pada umumnya, financial distress dikaitkan dengan jumlah utang yang lebih besar dari aktiva yang dicerminkan dengan rasio leverage yang besar atau lebih dari 1 . Namun berdasarkan statistika deskriptif, tidak ada perusahaan yang memiliki nilai DAR diatas 1 . Hal ini membuktikan bahwa rasio leverage perusahaan agribisnis masih dalam taraf normal karena jumlah utang yang harus dibayar lebih rendah dari aktiva yang dimiliki perusahaan.

Tabel 3 Statistika deskriptif variabel bebas dan terikat perusahaan agribisnis 2010-2014

\begin{tabular}{lcccccr} 
Variabel & DSCR & DAR & EBITDA/TA & TATO & ROE & WC/TA \\
\hline Mean & 1.413 & 0.538 & 0.095 & 0.223 & 0.108 & -0.007 \\
Median & 1.582 & 0.530 & 0.078 & 0.217 & 0.111 & -0.028 \\
Maksimum & 10.842 & 0.985 & 0.365 & 2.152 & 0.916 & 0.368 \\
Minimum & -45.557 & 0.004 & -0.521 & 0.034 & -3.982 & -0.398 \\
Std. Dev. & 0.528 & 0.080 & 0.042 & 0.079 & 0.087 & 0.071 \\
\hline
\end{tabular}




\section{Analisis Financial Distress pada Perusahaan Agribisnis di Bursa Efek Indonesia}

Annisa Nurfajrina, Hermanto Siregar, \& Imam Tegub Saptono

Rasio EBITDA/TA memiliki nilai mean sebesar 0.095, median sebesar 0.078, dan standar deviasi sebesar 0.042 . Nilai minimum dan maksimum EBITDA/TA berasal dari perusahaan yang sama yaitu DSFI. Nilai EBITDA/TA perusahaan DSFI tahun 2010 sebesar -0.521 menjadi nilai minimum rasio ini. Pada tahun 2010, perusahaan melakukan reklasifikasi aset tetapnya yang berupa kapal serta mesin dan peralatan. Kedua jenis aset ini akan dijual sehingga dipindahkan ke aset tetap yang tidak digunakan. Tindakan reklasifikasi aset tetap mengakibatkan perusahaan memiliki nilai depresiasi negatif yang berdampak pula terhadap rasio EBITDA yang negatif. Nilai EBITDA perusahaan DSFI kembali positif di tahun 2013 dan didukung oleh nilai depresiasi yang cukup tinggi. Sehingga pada tahun ini perusahaan DSFI memiliki nilai EBITDA/TA maksimum yakni sebesar 0.365.

Rata-rata nilai TATO sebesar 0.223 dengan median sebesar 0.217 dan standar deviasi sebesar 0.079. Nilai maksimum berasal dari perusahaan SMAR tahun2011 yakni sebesar 2.152.SMAR mampu menghasilkan total penjualan yang tinggi dengan nilai aset yang cukup rendah pada tahun ini. Di tahun yang sama, perusahaan IIKP menghasilkan nilai minimum TATO sebesar 0.034. karena perusahaan kurang efektif dalam menggunakan aset yang dimilikinya.

Nilai mean, median, serta standar deviasi variabel ROE berturut-turut sebesar 0.108, 0.111, dan 0.079. Nilai minimum sebesar -3.982 dimiliki oleh CPRO pada tahun 2012 karena memiliki nilai laba bersih yang negatif. Namun perusahaan ini dapat meningkatkan kinerjanya di tahun 2013, perusahaan menghasilkan laba bersih yang tinggi dan berdampak terhadap peningkatan nilai $\mathrm{ROE}$ hingga menjadi nilai tertinggi di variabel ini yakni sebesar 0.916 .

WC/TA memiliki nilai mean dan median negatif yakni sebesar -0.007 dan -0.028 . Nilai standar deviasi sebesar 0.071 lebih kecil dibandingkan dengan nilai mean menunjukkan bahwa sebaran data yang dimiliki variabel tersebut sangat besar jauh dari nilai rata-ratanya. Nilai maksimum sebesar 0.368 dimiliki oleh DSFI di tahun 2011dan nilai minimum sebesar -0.389 dimiliki oleh CPRO di tahun 2012. Pada tahun 2011, DSFI memiliki jumlah aset lancar yang lebih besar dibandingkan kewajiban lancar yang harus dibayar sehingga berdampak terhadap besarnya rasio WC/TA. Jumlah kewajiban lancar CPRO tahun 2012 lebih besar dua kali lipat dibandingkan dengan aset lancar yang dimilikinya. Hal ini menyebabkan nilai working capital dan rasio WC/TA yang negatif.

\section{Hasil Pengujian Asumsi Klasik}

Sebelum dilakukan analisis regresi, data yang ada diuji terlebih dahulu dengan serangkaian uji asumsi klasik. Berdasarkan hasil uji, diketahui bahwa data bebas dari masalah asumsi klasik sehingga data yang digunakan telah memenuhi kriteria.

1. Uji Multikolinearitas

Data lolos dari multikolinearitas karena nilai koefisien korelasi antar variabel tidak ada yang lebih dari 0.8. Hal ini berarti tidak ada variabel dalam penelitian ini yang memiliki keterkaitan yang kuat.

2. Uji Normalitas

Nilai probabilitas sebesar 0.36 yang dihasilkan oleh JB test menunjukkan bahwa data lolos uji normalitas karena nilainya lebih besar dari alpha 0.05 . Hal ini berarti bahwa nilai residual (error) berdistribusi dengan normal.

3. Uji Heteroskedastisitas

White heteroscedasticity test menunjukan bahwa nilai $\mathrm{Obs}^{*} \mathrm{R}$-squared $>$ alpha 0.05 yaitu sebesar 0.47 . Data yang dimiliki homoskedastisitas atau terbebas dari masalah heteroskedastisitas.

4. Uji Autokorelasi

Hasil pengujian menggunakan metode Breusch-Godfrey menunjukkan bahwa nilai pvalue Obs*R-squared >alpha 0.05 yakni sebesar 0.07. Dengan demikian, data lolos dari masalah autokorelasi. 


\section{Jurnal Keuangan dan Perbankan | KEUANGAN}

Vol. 20, No.3, September 2016: 448- 457

5. Uji Stasioneritas

Metode LLC (Levin, Lin, \& Chu) digunakan untuk mengetahui apakah data panel yang dimiliki stasioner atau non-stasioner. Keseluruhan variabel menunjukan bahwa nilai probabilitas < alpha 0.05. Seluruh variabel menolak hipotesis null yang berarti data stasioner atau tidak memiliki unit root.

\section{Hasil Analisis Regresi Data Panel}

Pemilihan model terbaik dipilih menggunakan uji chow, uji hausman, dan uji lagrange multiplier (Gujarati,2003). Uji chow digunakan untuk memilih antara pooled least square (PLS) atau fixed effect model (FEM). Uji hausman digunakan untuk memilih antara fixed effect model (FEM) atau random effect model (REM). Hasil pengujian menggunakan uji chow menunjukkan model terbaik yang digunakan adalah PLS, sedangkan hasil uji hausman menunjukkan bahwa REM adalah yang terbaik. Oleh karena itu, dilakukan uji lagrange multiplier untuk memutuskan model yang tepat untuk digunakan antara PLS dan REM. Berdasarkan hasil uji tersebut, didapatkan bahwa model model terbaik yang tepat untuk digunakan adalah PLS.

\section{PEMBAHASAN}

Berdasarkan pengamatan yang dilakukan pada taraf nyata $5 \%$, terlihat bahwa rasio EBITDA/
TA, ROE, dan TATO berpengaruh positif secara signifikan terhadap nilai DSCR. Sementara variabel lainnya yaitu, DAR dan WC/TA berpengaruh positif namun tidak signifikan terhadap nilai DSCR.

EBITDA merupakan keuntungan sebelum dikurangi bunga dan pajak serta mencakup nilai depresiasi dan amortisasi. Nilai EBITDA/TA menunjukkan tingkat efisiensi perusahaan dalam menghasilkan keuntungan dari aset yang dimilikinya. Rasio ini secara signifikan berpengaruh positif terhadap nilai DSCR. Variabel EBITDA/TA memiliki nilai koefisien regresi terbesar dibandingkan variabel lainnya yaitu sebesar 10.902. Hal ini sesuai dengan penelitian Pranowo et al. (2010) yang menyatakan bahwa rasio efisiensi yang diwakilkan oleh EBITDA/TA memiliki koefisien yang cukup besar dan berpengaruh signifikan terhadap nilai DSCR. Lemmon et al.(2009) juga menyatakan bahwa rasio ini berpengaruh signifikan dalam mengidentifikasi perusahaan yang mengalami financial distress dan economic distress.

Rasio profitabilitas yang diwakilkan oleh ROE memengaruhi DSCR secara signifikan. Koefisien ROE yang bertanda positif sebesar 0.829 menandakan apabila variabel lainnya diasumsikan tetap, maka peningkatan 1 satuan variabel ROE akan meningkatkan nilai DSCR sebanyak 0.829. Semakin besar tingkat pengembalian atas modal yang dimiliki perusahaan maka semakin besar nilai DSCR perusahaan tersebut. Nilai DSCR yang besar

Tabel 5 Hasil estimasi model DSCR

\begin{tabular}{lcccc}
\hline Variabel bebas & Koef. Regresi & Std. Error & t-Statistic & Prob. \\
\hline C & -0.574 & 0.752 & -0.763 & 0.449 \\
DAR & 0.637 & 1.236 & 0.516 & 0.608 \\
EBITDA/TA & 10.902 & 2.203 & 4.949 & $\mathbf{0 . 0 0 0}$ \\
ROE & 0.829 & 0.409 & 2.026 & $\mathbf{0 . 0 4 8}$ \\
TATO & 1.163 & 0.225 & 5.173 & $\mathbf{0 . 0 0 0}$ \\
WC/TA & 0.317 & 1.289 & 0.245 & 0.807 \\
\hline R-squared & 0.828 & F-statistik & 47.117 & \\
Adjusted R-squared & 0.810 & Prob. (F-stat.) & 0.000 & \\
\hline
\end{tabular}




\section{Analisis Financial Distress pada Perusahaan Agribisnis di Bursa Efek Indonesia}

Annisa Nurfajrina, Hermanto Siregar, \& Imam Tegub Saptono

merupakan indikator perusahaan yang terbebas dari kondisi financial distress.Hal ini mendukung penelitian Kamaludin dan Pribadi (2011) yang menyatakan bahwa ROEberpengaruh secara signifikan terhadap prediksi kondisi financial distress suatu perusahaan. Dalam penelitiannya, Haq et al. (2013) menemukan fakta apabila ROE meningkat maka kemungkinan perusahaan mengalami financial distress akan menurun.Nilai ROE yang tinggi dapat menghasilkan nilai pengembalian atas investasi semakin tinggi sehingga menguntungkan para pemilik modal.

TATO berpengaruh posifif dan signifikan terhadap nilai DSCR dengan koefisien sebesar 1.162. Hal ini berarti jika nilainya meningkat 1 satuan, maka nilai DSCR bertambah sebesar 1.162. Rasio ini menunjukkan seberapa efektif perusahaan menggunakan sumber daya atau asetnya. Semakin besar nilai TATO menunjukkan bahwa efektivitas perusahaan tinggi dalam menghasilkan penjualan yang akan menghasilkan keuntungan optimal. Oleh karena itu, dibutuhkan perputaran aset yang cepat sehingga perusahaan dapat terhindar dari financial distress.Hasil penelitian ini sejalan dengan Noviandri (2014) yang membuktikan bahwa TATO berpengaruh signifikan terhadap financial distress perusahaan.Jaya et al.(2013) menyatakan bahwa pengaruh rasio perputaran total aktiva (TATO) terhadap kondisi financial distressmenunjukkan arah negatif. Semakin tinggi rasio perputaran total aktiva maka akan semakin kecil potensi terjadinya kondisi financial distresspada tahun berikutnya.

DAR tidak berpengaruh signifikan terhadap DSCR karena memiliki nilai p-value lebih besar dari alpha 0.05 yakni sebesar 0.608 . Hal ini berarti peningkatan maupun penurunan DAR tidak mengakibatkan perubahan terhadap nilai DSCR, sehingga tidak berpengaruh terhadap financial distress perusahaan.Hal ini tidak sesuai dengan hipotesis awal yang menyatakan bahwa DAR berpengaruh negatif signifikan terhadap nilai DSCR. Namun hasil penelitian ini mendukung penelitian sebelumnya yang dilakukan Putri dan Merkusiwati
(2014) serta Widarjo dan Setiawan (2009). Penelitian mereka membuktikan bahwa financial leverage yang diukur dengan DARtidak berpengaruh signifikan terhadap kemungkinan terjadinya financial distress perusahaan.

Rasio likuiditas yang diukur dengan WC/ TA menggambarkan perbandingan modal kerja bersih dengan total aktiva yang dimiliki perusahaan. Semakin tinggi rasio modal kerja terhadap total aktiva, maka kondisi keuangan perusahaan semakin sehat (Swantari \& Habibie, 2012). Akan tetapi, rasio ini tidak berpengaruh signifikan terhadap financial distress perusahaan agribisnis dikarenakan nilai p-value WC/TA sebesar 0.807 lebih besar dari alpha 0.05 . Pengaruh yang tidak signifikan dikarenakan tidak adanya perbedaan yang berarti antara kondisi likuiditas perusahaan sehat dan perusahaan yang mengalami financial distress.Hasil penelitian ini sesuai dengan penelitian Nurcahyono dan Sudharma (2014) yang menyatakan bahwa WC/TA tidak berpengaruh terhadap kondisi financial distress. Menurut Fitriyah dan Hariyati (2013), perbedaan komposisi aktiva lancar pada masing-masing perusahaan menyebabkan rasio WC/TA tidak berpengaruh terhadap financial distress.

Nilai R-squared yang dihasilkan model cukup besar yaitu sebesar $82.782 \%$. Hal ini menunjukkan bahwa variabel-variabel bebas mampu menjelaskan pengaruhnya terhadap variabel terikat sebesar $82.782 \%$. Sisanya yaitu $17.218 \%$ merupakan faktorfaktor lain diluar variabel penelitian yang juga mempengaruhi kondisi financial distress perusahaan.

\section{KESIMPULAN}

Variabel yang berpengaruh signifikan terhadap financial distress perusahaan agribisnis adalah EBITDA/TA,ROE, dan TATO. Ketiga variabel tersebut memiliki pengaruh positif dan signifikan terhadap nilai DSCR. Semakin besar variabel tersebut, maka semakin besar nilai DSCR sehingga perusahaan terbebas dari kondisi finan- 


\section{Jurnal Keuangan dan Perbankan | KEUANGAN}

Vol. 20, No.3, September 2016: 448-457

cial distress. Sedangkan DAR dan WC/TAtidak memiliki pengaruh yang signifikan terhadap nilai DSCR.

\section{SARAN}

Rasio yang berpengaruh signifikan terhadap financial distress (EBITDA/TA, ROE, dan TATO) perlu diperhatikan oleh manajemen perusahaan karena hal ini berkaitan dengan kemungkinan perusahaan mengalami kebangkrutan.

Perlu dilakukan penelitian lebih lanjut dengan mengkaji faktor-faktor lain yang mempengaruhi kondisi financial distress perusahaan agribisnis, baik menggunakan rasio keuangan lainnya maupun faktor eksternal seperti inflasi, nilai tukar rupiah, dan suku bunga.

\section{DAFTAR PUSTAKA}

Ahmad GN. 2013. Analysis of financial distress in indonesian stock exchange. Review of Integrative Business and Economic Research 2(2):521-533.

Andrade G, Kaplan SN. 1998. How costly is financial (not economic) distress? Evidence from highly leveraged transactions that became distressed. Journal of Finance 53(5):1442-1493.

Arasy I, Harlendro. 2014. Analisis current ratio, debt to asset ratio, return on asset, inventory turn over, dan sales growth untuk memprediksi financial distress. Jurnal Ilmiah Mahasiswa FEB Universitas Brawijaya 2(1):1-14.

Alifiah MN, Salamudin N, Ahmad I. 2013. Prediction of financial distress companies in the consumer products sector in Malaysia. Jurnal Teknologi (Social Sciences) 64(1):85-91.

Arlinda, Achsani NA, Saptono IT. 2015. Impact of merger and acquisition on financial performance and financial distress: empirical evidence from indonesian telecommunication industry. European Journal of Business and Management 7(25):125-133.

[BPS] Badan Pusat Statistik. 2015a. Distribusi produk distribusi bruto seri 2010 triwulanan atas dasar harga berlaku menurut lapangan usaha (persen),
2010-2014 [Internet]. Jakarta (ID): Badan Pusat Statistik; [diunduh 2015 November 3]. Tersedia pada: http://www.bps.go.id/linkTabelStatis/ view/id/1253.

2015b. Laporan perekonomian Indonesia 2015. Jakarta (ID): Badan Pusat Statistik.

Fitriyah I, Hariyati. 2013. Pengaruh rasio keuangan terhadap financial distress pada perusahaan properti dan real estate. Jurnal Ilmu Manajemen 1(3):760-773.

Gujarati DN. 2003. Basic Econometrics. Singapore (SG): McGraw-Hill.

Haq S, Arfan M, Siswar D. 2013. Analisis rasio keuangan dalam memprediksi financial distress (studi pada perusahaan yang terdaftar di bursa efek indonesia). Jurnal Akuntansi Pascasarjana Universitas Syiah Kuala 2(1):37-46.

Hidayat MA, Meiranto W. 2014. Prediksi financial distress perusahaan manufaktur di Indonesia. Diponegoro Journal of Accounting 3(3):1-11.

Jaya MSA, Wahyuni LM, Putra IMDW. 2013. Pengaruh rasio likuiditas, profitabilitas, dan aktivitas terhadap financial distress pada industri pakaian jadi dan produk tekstil lainnya yang terdaftar di bursa efek indonesia tahun 2004-2010. Jurnal Bisnis dan Kewirausahaan 9(1):56-67.

Kamaludin, Pribadi KA. 2011. Prediksi financial distress kasus industri manufaktur pendekatan model regresi logistik. Jurnal Ilmiah STIE MDP 1(1):11-23.

[KEMENTAN] Kementerian Pertanian. 2015a. Ekspor komoditi pertanian persubsektor periode JanuariDesember 2014 [Internet]. Jakarta (ID): Pusat Data dan Sistem Informasi Pertanian. Basis Data Ekspor Impor Komoditi Pertanian; [diunduh 2015 September 20]. Tersedia pada: http://aplikasi. pertanian.go.id/eksim2012/hasilekspor Subsek.asp.

2015b. Rencana Strategis Kementerian Pertanian Tahun 2015-2019. Jakarta (ID): Kementerian Pertanian.

Lemmon M, Ma YY, Tashjian E. 2009. Survival of the fittest? Financial and economic distress and restructuring outcomes in Chapter 11. Third Singapore International Conference on Finance 2009 doi:10.2139/ssrn.1325562. 


\section{Analisis Financial Distress pada Perusahaan Agribisnis di Bursa Efek Indonesia}

Annisa Nurfajrina, Hermanto Siregar, \& Imam Tegub Saptono

Noviandri T. 2014. Peranan analisis rasio keuangan dalam memprediksi kondisifinancial distressperusahaan sektor perdagangan. Jurnal Ilmu Manajemen 2(4):1655-1665.

Nurcahyono, Sudharma K. 2014. Analisis rasio keuangan untuk memprediksi kondisi financial distress. Management Analysis Journal 1(3):1-6.

Platt HD, Platt MB. 2002. Predicting corporate financial distress: reflecting on choice-based sample bias. Journal of Economics and Finance 26(2):184-199.

Pranowo K, Achsani NA, Manurung AH, Nuryantono N. 2010. The dynamics of corporate financial distress in emerging market economy: empirical evidence from the Indonesian Stock Exchange 20042008. European Journal of Social Sciences 16(1):138149.

Putri NWKA, Merkusiwati NKLA. 2014. Pengaruh mekanisme corporate governance, likuiditas, leverage, dan ukuran perusahaan pada financial distress.E-Jurnal Akuntansi Universitas Udayana 7(1):93-106.

Ruster J. 1996. Mitigating commercial risks in project finance. Public Policy for Private Sector. New York (US): The World Bank.
Rizaldi AF. 2000. Analisis kinerja dan strategi investasi kelompok saham sektor agribisnis di Bursa Efek Jakarta (studi kasus periode pra krisis - krisis pemulihan) [Tesis]. Bogor (ID): Institut Pertanian Bogor.

Stulpiniene V, Mazure G. 2013. Finding financial distress predictor of farms. Rural Development 2013 6(1): 383-388.

Swantari A, Habibie FH. 2012. Prediksi financial distress berdasarkan kemampuan kinerja keuangan pada industri properti. MITTRA 3(1):1-18.

Widarjo W, Setiawan D. 2009. Pengaruhrasio keuangan terhadap kondisi financial distress perusahaan otomotif.Jurnal Bisnis dan Akuntansi 11(2): 107-119.

Widati WL, Pratama BA. 2015. Pengaruh current ratio, debt to equity ratio, dan return on equity, untuk memprediksi kondisi financial distress. Journal of Accounting and Banking 4(1):1-13. 